\title{
Establishment of empirical relations between fuel moisture content and the normalised difference vegetation index
}

\author{
M. Castro ${ }^{1,2}$, J.C. Parra ${ }^{2,3 *}$, L. J. Morales ${ }^{4}$ and C.Salas ${ }^{5}$ \\ ${ }^{1}$ Master's Programme in Engineering Sciences, Mention Electrical Engineering. Universidad de La Frontera. Temuco, Chile. \\ ${ }^{2}$ Center for Optics and Photonics. Universidad de Concepción, Concepción, Chile. ${ }^{3}$ Department of Physical Sciences. Faculty of \\ Engineering and Sciences. Universidad de La Frontera. Temuco, Chile ${ }^{4}$ Department of Environmental Sciences and Renewable \\ Natural Resources. Universidad de Chile. Santiago, Chile. ${ }^{5}$ Department of Forest Sciences.Faculty of Agricultural and Forestry \\ Sciences.Universidad de La Frontera. Temuco, Chile. "Corresponding author: juan.parra@ufrontera.cl
}

\begin{abstract}
The object of the present research is to establish empirical relations between the Fuel Moisture Content (FMC) and the Normalised Difference Vegetation Index (NDVI) in pasture samples. The study area was the Carillanca Experimental Centre belonging to the Institute of Agriculture and Livestock Research (Instituto de Investigaciones Agropecuarias - INIA), Araucanía Region, Chile. The study period ran from November 2011 to January 2012, in order to determine the variation in vegetation moisture content from spring, when plant cover is most vigorous, to summer when it declines to a minimum due to the summer drought. The application of a linear adjustment model produced correlation coefficients higher than 0.6.
\end{abstract}

Keywords: Fuel content, normalized difference vegetation index, pasture

\section{Introduction}

Quantifying the humidity content is very important, as it is one of the key variables for the characterization of the earth's floor and the knowledge it producesfor the improvement ofirrigation management in vegetation (Zhang et al., 2013; Shukla et al., 2013). More detailed knowledge in space and time of the moisture content of a crop under irrigation would enable farmers to manage water resources more effectively, supplying the crop with water when and where it was vitally needed. Furthermore, the prevention of natural disasters such as drought and forest fires (Cocero et al., 2000; Chuvieco et al., 2001; Yebra et al., 2005 ; Yebra et al., 2008a; Yebra et al., 2008b). in shrubby or herbaceous vegetation the moisture content is a key parameter for explaining the phenological evolution of plant formations, allowing deficit situations to be detected which might lead to critical deterioration in plant tissue (Sepulcre et al., 2006). Because the moisture content of plants is inversely related to their flammability and combustibility, it is very important for the prevention of natural disasters such as drought and forest fires (Cocero et al., 2000; Chuvieco et al., 2001; Yebra et al., 2005 ; Yebra et al., 2008a; Yebra et al., 2008b). 
It can be estimated by gravimetric methods, or with models which use information from remote sensors on board satellite platforms as input (Yebra, 2008). The advantage of the latter is that they provide information on moisture content on a regional scale, while the former are of a more local nature. However for this type of estimation to be reliable, the effects of moisture on the reflectivity of the vegetation must be studied, in order to isolate the bands which are most sensitive in remote observation and determine critical effect levels (Vaughan, 2001).

In the context of research into correlations between biophysical variables to allow moisture content to be estimated from satellite platforms, the present contribution is oriented towards finding empirical relations between the moisture content and the normalised difference vegetation index.

\section{Materials and Methods}

\subsection{Study area}

The study area was the Carillanca Experimental Centre belonging to the Institute of Agriculture and Livestock Research (Instituto de InvestigacionesAgropecuariasINIA), located between $38^{\circ}$ and $39^{\circ}$ south, $20 \mathrm{~km}$ north-east of Temuco, at kilometer 9.5 of the CajónVilcún road. The experimental farm, located in the IX (Araucanía) Region of Chile, covers 530 hectares; it has irrigated flat land with volcanic ash soil, and dry rolling land with volcanic ash and transition soils, making it representative of a large part of the Region. The climate is characterised by an average annual temperature of $10^{\circ} \mathrm{C}$, with average maximum in the hottest month (January) of $21.5^{\circ}$ and average minimum in the coldest month (July) of $2.3^{\circ} \mathrm{C}$. The average annual rainfall is $1394 \mathrm{~mm}$, the wettest month being May with $236.6 \mathrm{~mm}$. The annual pan evaporation is $921 \mathrm{~mm}$, with a monthly maximum in January of $161 \mathrm{~mm}$ and minimum in July of $20 \mathrm{~mm}$ (Novoa and Villaseca, 1989).
A plot measuring $20 \mathrm{~m}$ by $20 \mathrm{~m}$ was established in the study area, from which samples of pasture (genus Festuca) were taken and subsequently stored in ziploc bags for transfer to the laboratory. The samples were taken between 12:00 and 16:00 hrs, over the period November 2011 to January 2012, in order to determine the variation in vegetation moisture content from spring, when plant cover is most vigorous, to summer when it declines to a minimum due to the summer drought.

\subsection{Spectral reflectivity of samples}

To record its reflectivity, each sample was placed inside a low reflectivity chamber, the sides of which were lined with high absorption black filter paper. This isolated the sample and prevented reflectivity interference from nearby objects.

The sample was illuminated with two $500 \mathrm{~W}$ halogen lights in parallel, at an angle of $45^{\circ}$, and kept lit for minimum 6 minutes, in order to stabilise the light source and diminish the effect of shadow. Reflectivity measurements were recorded for each sample using a PS-100 spectroradiometer, band-width $350-1000 \mathrm{~nm}$ and resolution $0.5 \mathrm{~nm}$. The reflectivity measurements were taken vertically, and the reflectivity of a calibrated reference target (Spectralon) was taken before each measurement. Once the reflectivity records had been obtained, the moisture content and vegetation index were estimated.

\subsection{Estimation of moisture content}

The samples were weighed (humid weight) in a scale accurate to 0.01 gr. They were then placed in an oven at $60^{\circ} \mathrm{C}$ for $48 \mathrm{hrs}$ for dessication (higher temperatures lead to a loss of biomass). The sample was then weighed again (dry weight). With this information, the moisture content was calculated in the form of the FMC (Fuel Moisture Content) index, defined as:

$$
F M C=\frac{\left(W_{h}-W_{d}\right)}{W_{d}} \times 100
$$


$\mathrm{W}_{\mathrm{h}}$ is the humid weight and $\mathrm{W}_{\mathrm{d}}$ the dry weight, i.e. that obtained after dessication of the sample. The result is expressed as a percentage of the dry weight.

\subsection{Estimation of the vegetation index}

The vegetation index is calculated from the reflectivity values at different wavelengths. It is used for extracting information on the vegetation while minimising the influence of other external factors such as the optical properties of the soil, solar irradiance, etc. (Sobrino, 2000).

More than twenty vegetation indices can be found in the literature, however the most commonly used, due to its mathematical simplicity and ease of use, is the Normalized Difference Vegetation Index (Rouse et al., 1974):

$$
N D V I=\frac{\rho_{\text {nir }}-\rho_{v}}{\rho_{v}+\rho_{\text {nir }}}
$$

$P_{\mathrm{v}}$ and $P_{\text {nir }}$ are the reflectivities in the visible and near infra-red regions. NDVI takes values in the range -1.0 to 1.0 ; negative values indicate surfaces free of vegetation, such as water, snow or cloud, and increasing positive values indicate increasing levels of vegetation.

Integrated reflectivity values were used to obtain vegetation indices.

$$
\rho_{\Delta \lambda}=\int_{\lambda_{1}}^{\lambda_{2}} \rho(\lambda) d \lambda
$$

The spectral ranges selected were matched with those found in the ASTER (Advanced Spaceborne Thermal Emission and Reflection Radiometer) and MODIS (Moderate-Resolution Imaging Spectroradiometer) sensors on board the TERRA satellite platform. Both sensors have band-widths in the visible and near infra-red regions: ASTER (v: 520-690 nm; nir: 760$860 \mathrm{~nm}$ ), MODIS (v: 620-670 nm; nir: 841-876 nm).

\section{Results}

\subsection{Reflectivity records}

Figure 1 shows the spectral signature corresponding to the typical behaviour of a sample of pasture, derived from the reflectivity records obtained.

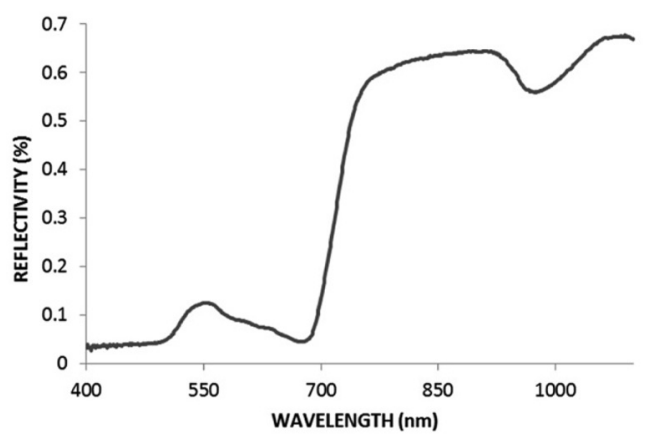

Figure 1. Spectral signature of a pasture sample

As can be seen from the figure, the reflectivity varies widely with the wavelength, with minimum values in the visible spectrum $(400-700 \mathrm{~nm})$ corresponding to blue $(436-495 \mathrm{~nm})$ and red $(627-770 \mathrm{~nm})$, related to the chlorophyll in the vegetation. The lowest reflectivity values in fact coincide with the maximum absorption values, corresponding in these intervals to chlorophyll. Among the maximum absorption values is a relative maximum in the reflectivity, around 550 $\mathrm{nm}$, corresponding to the green (495-566 nm) of the vegetation. Reflectivity is high towards the near infrared region (700-1100 $\mathrm{nm}$ ), associated with the vigorous state of the vegetation, the proportion of green cover and the healthy leaves.

\subsection{Moisture content}

Figure 2 shows the evolution over time of the moisture content. There is a clear contrast between spring (value close to $400 \%$ ) and summer (around 40\%), which agrees with the reduced precipitation and the higher temperatures. 


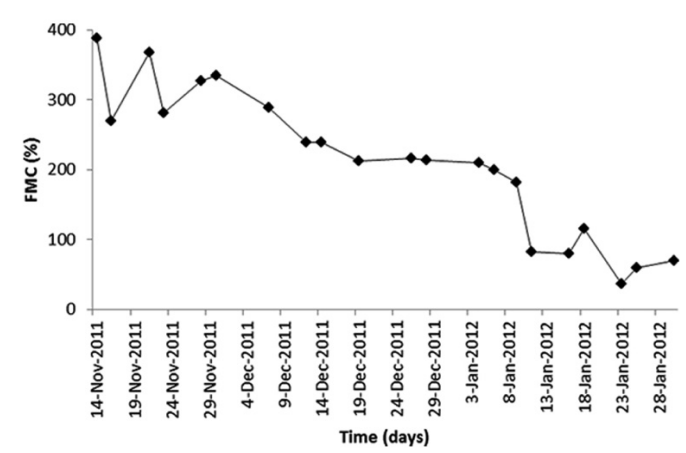

Figure 2. Evolution over time of the moisture content (\%)

\subsection{Ratios between the moisture content and the} normalised difference vegetation index

Figure 3 shows the graphs for FMC (\%) as a function of NDVI for the ASTER and MODIS sensors, with the straight line for linear fit, linear regression model and correlation coefficient.
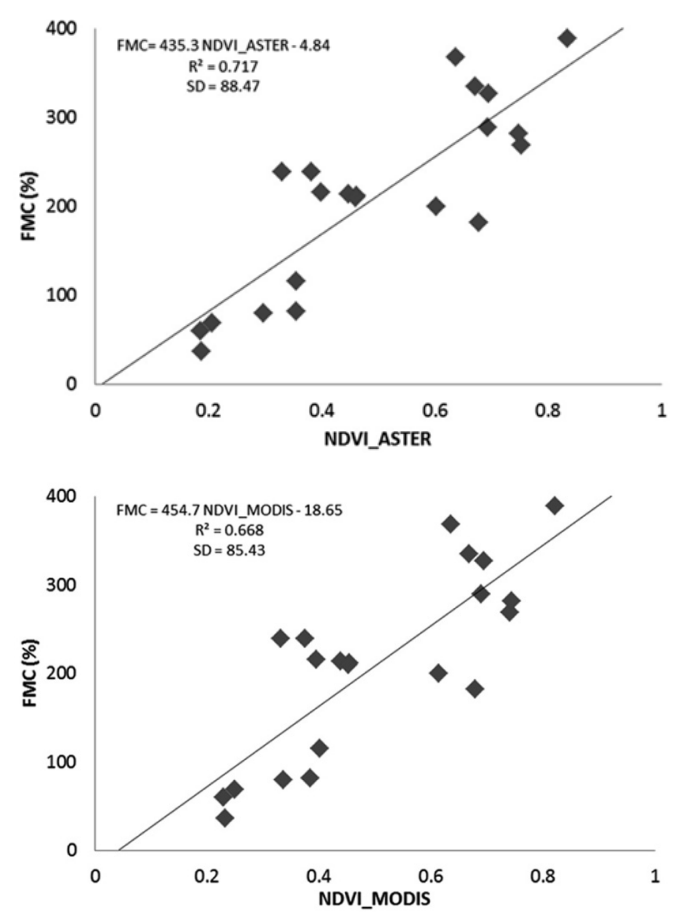

Figure 3. Variability of FMC (\%) as a function of NDVI for the ASTER and MODIS sensors

The correlation signs are consistent with expectations. The NDVI measures the vigour of the vegetation (principally its chlorophyll content); therefore when the moisture content increases, other physiological processes of the vegetation do likewise, implying an increase in NDVI. A summary of the statistical analysis is given in Table 1.

Table 1. Statistical analysis of FMC (\%) as a function of NDVI for the ASTER and MODIS sensors a

$$
\text { BIAS }=\sum_{i=1}^{n} \frac{(\text { FMC observed }-F M C \text { estimated })}{n}
$$

b

$$
R M S D=\left[\sum_{i=1}^{n} \frac{(\text { FMC observed-FMC estimated })^{2}}{n}\right]^{0.5} \text { 'Slope }
$$

of linear fit; d intercept of linear fit; ${ }^{\text {e }}$ correlation coefficient.

\begin{tabular}{|c|c|c|c|c|c|}
\hline FMC & BIAS $^{\mathrm{a}}(\%)$ & RMSD $^{\mathrm{b}}(\%)$ & $\mathrm{a}^{\mathrm{c}}$ & $\mathrm{b}^{\mathrm{d}}(\%)$ & $\mathrm{R}^{2 \mathrm{e}}$ \\
\hline ASTER & -0.00019 & 54.21 & 435.3 & -4.84 & 0.71 \\
\hline MODIS & -0.00169 & 58.69 & 454.7 & -18.65 & 0.66 \\
\hline
\end{tabular}

The FMC values observed and estimated, together with the linear trend lines 1:1, for the ASTER and MODIS sensors are shown in Figure 4.

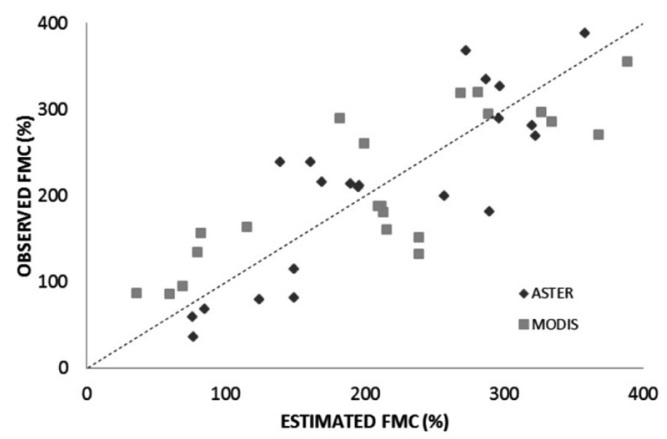


Figure 4. Observed FMC values contrasted with estimated FMC values for the ASTER and MODIS sensors. The straight line of the linear trend 1:1 is indicated.

\section{Conclusions}

The results of this study indicate that the reflectivity records for the different samples vary widely with the wavelength; the spectral reflectivity curves show maximum and minimum values associated with absorption bands. Minimum values appear in the visible spectrum region which correspond to maximum chlorophyll absorption, while the near infra-red region presents an increase in reflectivity, associated with the vigour of the vegetation, the proportion of green cover and the health of the leaves.

The evolution over time of the moisture content of the pasture shows marked variations between spring (close to $400 \%$ ) and summer (around $40 \%$ ), resulting from reduced precipitations and higher temperatures. When the FMC index is correlated statistically with the NDVI, as estimated for spectral bands located in the visible and near infra-red spectrum in the ASTER and MODIS sensors, linear correlation coefficients higher than 0.6 are obtained. This means that it is possible to estimate the moisture content based on information provided by satellite platforms at a spatial resolution suitable for agronomy and forestry studies.

\section{Acknowledgements}

The authors are grateful for the financial support provided by Project DI13-0009 of Universidad de La Frontera; and the Instituto de Investigaciones Agropecuarias (INIA), Carillanca for making sampling areas available. Juan C. Parra and Manuel Castro are grateful for CONICYT Grant PFB08-024.

\section{References}

Chuvieco, E., Salas, F. J., Aguado, I., Cocero, D. Riaño, D. 2001. Estimación del estado hídrico de la vegetación a partir de sensores de alta y baja resolución. GeoFocus. 1, 1-16.

Cocero, D., Riaño, D, Chuvieco, E. 2000. Estimación de la Humedad de Diferentes Especies Vegetales Mediterráneas mediante distintos sensores de Teledetección. Tecnologías Geográficas para el Desarrollo Sostenible. Departamento de Geografía. Universidad de Alcalá. 200-221.

Novoa, S., Villaseca, C. 1989. Mapa agroclimático de Chile. Instituto de Investigaciones Agropecuarias. Santiago, Chile, $221 \mathrm{p}$.

Rouse, J.W., Haas, R.W., Shell, J.A., Deering, D.W, Harlan, J.C. 1974. Monitoring the vernal advancement and retrogradation of natural vegetation, NASA/GSFC, Type III, Final Report, Greenbelt. M.A., USA.

Sepulcre-Cantó, G., Zarco-Tejada, P.J., JimenezMuñóz, J.C., Sobrino, J.A., De Miguel, E., Villalobos, F.J. 2006. Detection of water stress in an olive orchard with thermal remote sensing imagery. Agricultural and Forest Meteorology. 136, 31-44.

Sobrino, J.A. 2000. Teledetección. Universidad de Valencia, Valencia, $467 \mathrm{p}$.

Shukla, A.,Vyas, D., Anuradha, J. 2013. Soil depth: an overriding factor for distribution of arbuscularmycorrhizal fungi. J. Soil Sci. Plant Nutr. 13 (1), 23-33.

Vaughan, P. 2001. Estimación de contenido de humedad de la vegetación mediante espectroradiometría. Trabajo de investigación tutelado, Universidad de Alcalá, Alcalá de Henares, España, $105 \mathrm{p}$. 
Yebra, M., de Santis, A., Chuvieco, E. 2005. Estimación del peligro de incendios a partir de teledetección y variables meteorológicas: variación temporal del contenido de humedad del combustible". Recursos Rurais. 1, 9-19.

Yebra, M. 2008. Estimación del contenido de humedad de vegetación mediterránea a partir de imágenes MODIS. Tesis Doctoral, Universidad Alcalá, España, 191 p.

Yebra, M., Chuvieco, E., Aguado, I. 2008a. Comparación entre modelos empíricos y de transferencia radiativa para estimar contenido de humedad en pastizales: Poder de generalización. Revista de Teledetección. 29, 73-90
Yebra, M., Chuvieco, E., Riaño, D. 2008b. Estimation of live Fuel Moisture Content from MODIS images for fire risk assessment. Agricultural and Forest Meteorology. 148, 523-536.

Zhang, J.G., Xu, X.W., Lei, J.Q., Li, S.Y., Hill, R.L., Zhao, Y. 2013. The effects of soil salt crusts on soil evaporation and chemical changes in different ages of Taklimakan Desert Shelterbelts. J. Soil Sci. Plant Nutr., 13 (4), 1019-1028. 